\title{
INDEPENDENT AGENCIES UNDER ATTACK: A SKEPTICAL VIEW OF THE IMPORTANCE OF THE DEBATE
}

\author{
Susan BartletT Foote*
}

The 1980s have witnessed two related but distinct attacks on independent agencies. ${ }^{1}$ One attack is grounded in constitutional theory. Soine have argued that independent agencies, those "strange amalgam[s]" that blend the functions of all three branches but are the creatures of none, violate the separation of powers doctrine in the Constitution. ${ }^{2}$ This approach has been labeled "neoclassical"3 or the "new formahisin." 4 These terms suggest a rediscovery of fundamental constitutional principles. Another attack proceeds froin an organizational perspective. Without clear lines of authority froin one branch of government, independent agencies are politically unaccountable, and therefore vulnerable to regulatory inefficiency and external inainpulation. ${ }^{5}$ In essence, the independent agency form is organizationally dysfunctional. This functional critique is alınost as old as independent agencies, yet the criticisin continues unabated.

These two lines of attack are distinct in several ways. One questions the constitutionality of a form, the other criticizes its function. The latter has a long history; the forner reflects a reawakening and expansion of

* Assistant Professor, School of Business Administration, University of California, Berkeley. J.D. 1977, University of California (Boalt Hall) School of Law. The author is grateful to her colleague, Professor Franklin E. Zirming of Boalt Hall, U.C. Berkeley, for his comments on this essay.

1. For purposes of this discussion, independence refers generally to agencies not within old line executive departments. The dommant ineaning of independence, then, is autonomy from presidential control. M. Reagan, Regulation: The Politics of Policy 66 (1987).

2. Miller, Independent Agencies, 1986 Sup. CT. REv. 41, 41-45. For similar views, see Currie, The Distribution of Powers after Bowsher, 1986 SUP. CT. REV. 19; Note, Incorporation of Independent Agencies into the Executive Branch, 94 Y ALE L.J. 1766 (1985).

3. Miller, supra note 2 , at 53.

4. Note, supra note 2 , at 1766 .

5. There is a large amoimt of hterature on agency capture, including the concern that independent agencies, with less clear lines of accountability, were inore susceptible than other institutious in government. For a summary of this view, see discussion in M. REAGAN, supra note 1, at 5266. The most cited work in this area is Stigler, The Theory of Economic Regulation, 2 BELI J. EcoN. \& MGMT. SCI. 3 (1971). Stigler's central thesis was that "as a rule, regulation is acquired by the industry and is designed and operated primarily for its benefit." Id. at 3. Another early critic of independent agency forn was Marver Bernstein, who beheved that the dogma of independence posed a threat to pohtical democracy. M. BERNSTEIN, REgUlating Business BY INDEPENDENT COMMISSION 128-30 (1955). 
a traditional argument. They are related in one significant way. Both critiques present themselves as politically neutral, questioning the form of regulatory agencies rather than their political purpose or effect. Joined together, as they often are, these two themes have become the 1980s assault on the fundamental legitimacy of independent agencies.

How can we explain the timing and intensity of the present debate on independent agency structure? After all, independent agencies have been around for one hundred years, ${ }^{6}$ and have been created to accomplish myriad complex governmental tasks. One way to understand this controversy is in relation to the underlying pohtical context $m$ which it has arisen. The attack on the imperial presidency had its beginnings in the post-Watergate period. From 1974 to 1980 , Congress flexed its growing political muscles. Congress used its power to accomphish goals that were politically liberal. Among its activities was the creation of numerous administrative agencies to implement social regulation im pursuit of the liberal agenda. ${ }^{7}$ Congress also passed legislation that put constraints on executive power in the wake of the Watergate scandal. ${ }^{8}$

President Reagan's election in 1980 presaged a resurgent executive branch that challenged the hegenony of Congress. The White House began to use its power on behalf of conservative goals. The executive branch confronted two significant political problems. First, it was faced with the liberal political legacy, including regulatory agencies whose mandates conflicted with administration policy. Second, conservatives could not consistently constrain Congress, which constantly threatened the administration's ability to accomphsh its ideological goals.

The constitutional and functional arguments are the by-products of this epic political struggle. Regulators always seem vuhrerable to criticism and can be attacked on functional grounds. Even better, if independent agencies were declared unconstitutional, these unruly bureaucracies would be absorbed by the executive branch. ${ }^{9}$ The result

6. The first independent agency vas the Interstate Commerce Commission, established in 1887. See M. BERNSTEIN, supra note 5, at 3.

7. The list of agencies created in the 1970 s is long, although not all of them were mdependent in form. Key independent agencies include the Consumer Product Safety Commission (1972). The Environmental Protection Agency (1969) is in a category of its own: a line agency, reporting to the President, but independent of any cabinet department.

8. One important piece of legislation was the Ethics in Government Act of 1978, Pub. L. No. 95-512, 92 Stat. 1824 (codified as amended in scattered sections of 2 U.S.C., 5 U.S.C., 5 U.S.C. app., 18 U.S.C., 28 U.S.C., 28 U.S.C. app., and 39 U.S.C.), which was recently unsuccessfully challenged on separation of powers grounds, see infra note 13 and accompanying text.

9. Solne have argued that independent agencies are "arms of Congress" and thus part of the legislative branch. This seems to be stretching reality. As Miller stated: "The 'arm of Congress" theory is typically unsupported by argument... The fallacy in the argument is too grotesque to bear elaboration." Miller, supra note 2, at 64 (footnote omitted). 
would be, at least in the short run, fewer obstacles to the administration's policies. In these pages, I wish to take the neutral critiques at face value, discussing both the constitutional and functional attacks of the past six years in light of a longer empirical tradition of studies of regulation. My conclusion is that of the noncombatant academic: the abolition of independent agencies would not matter much.

Can this be? The intensity of the debate easily leads one to assume that significant consequences will ensue if independent agencies disappear. On the surface, there would indeed be major structural shifting. However, a closer look at the hiterature provides a useful perspective. Political scientists have asked these questions: To what extent do the formal structural ties of agencies to the federal branches affect regulatory outcomes? How much does form matter? The conclusion of their empirical work points to the limited relevance of this debate to political outcomes.

\section{The Constitutional Critique}

The constitutional argument against independent agencies is a straightforward one. It is clearly reflected in Bowsher v. Synar. ${ }^{10}$ In this case, the Supreine Court held that the Comptroller General of the United States could not exercise the functions that the Gramm-Rudman-Hollings Act delegated to him. Those functions were descried as "executive," and incompatible with the power Congress retained to renove the Comptroller from office by joint resolution. Congressional removal power over an officer performing executive functions would constitute an impermissible encroachment on the separation of powers doctrine. Admittedly, the Court asserted that the opmion did not cast "doubt upon the status of 'independent' agencies because no issues involving sucl agencies [were] presented."11 However, a logical extension of the reasoning in the case, as well as dicta in the lower court opinion, ${ }^{12}$ suggest that independent agencies would be vulnerable if challenged directly.

The Court recently examined a related problem in Morrison v. Olson. ${ }^{13}$ Independent counsel Alexia Morrison won a stunning 7-1 reversal of a D.C. Circuit opinion lolding that the independent counsel provisions of the 1978 Ethics in Government Act violated the separation of

10. 478 U.S. 714 (1986).

11. Id. at 725 n.4.

12. Synar v. United States, 626 F. Snpp. 1374, $1389-99$ (D.D.C.) (Scalia, Johnson \& Gasch, JJ.), aff'd sub nom. Bowsher v. Synar, 478 U.S. 714 (1986).

13. 108 S. Ct. 2597 (1988). 
powers principle. ${ }^{14}$

The legislation at issue in both cases threatened the immediate pohtical power of the executive branch. Can the formahistic approach be separated from the political imphications of such a view? Are the constitutional theorists oblivious to, or imphicitly supporting, this potential increase in executive power?

Adherents of the formalistic separation of powers doctrine in the executive branch appear to be motivated primarily by pohitical, not neutral goals. Conservatives withm the Reagan administration are clearly aware that the executive stands to gain from the use of constitutional arguinents, in these specific cases and if applied more generally. Former Attorney General Edwin Meese III has argued that the notion of agencies outside the executive branch should be abandoned. ${ }^{15}$ The Solicitor General's brief in the Gramm-Rudman Act case came as close as one can coine to a direct challenge to independent agencies. ${ }^{16}$ Indeed, political commentator Michael Kinsley argued that conservatives in the executive branch are using constitutional law simply to increase their power: "They think they will always control the executive branch, and they're boyishly eager to break down all the (inherently conservative) barriers to strong presidential action."17

This use of constitutional principles for political ends is not surprising. Reagan appointees have not hesitated to abandon their ideology when it suits their political purposes. For example, the administration has often invoked the primciples of "new federalism." New federalism, a central tenet of the 1980 campaign, advocated the return of power, arguably usurped by the federal government, to the states. ${ }^{18}$ The adımimstration, however, has enhanced federal power on a number of occasions. ${ }^{19}$ For example, the Reagan White House supported a federal

14. In re Sealed Case, 838 F.2d 476, 511 (D.C. Cir. 1988), rev'd sub nom. Morrison v. Olson, 108 S. Ct. 2597 (1988). Before the Supreme Court's Morrison opinion issued, scholars saw the case as part of a larger effort to reestablish firm boundaries between legislative and executive authority by groups unhappy with the power of independent regulatory agencies. See Coyle, Separation of Powers: A Classic, Nat'l L.J., May 2, 1988, at 3, 3, 22.

15. See Meese, Towards Increased Government Accountability, 32 FED. B. NEws \& J. 406 (1985) (reprint of Address Before Federal Bar Association, Sept. 13, 1985). 1377).

16. See Brief for the United States at 27-51, Bowsher v. Synar, 478 U.S. 714 (1986) (No. 85 -

17. Kinsley, Rightist Judicial Activism Rescinds a Popular Mandate, Wall St. J., Feb. 20, 1986, at 25 , cols. 3,6 .

18. For a discussion of new federalism, see Gray, Regulation and Federalism, 1 YALE J. REG. 93 (1983). Mr. Gray was counsel to the Vice President.

19. Preemption of state laws is the tool often used. Congressional power to preempt state laws arises from the supremacy clause. U.S. CONST. art. VI, cl. 2. There has been a trend whereby administrative agencies, both independent and executive, have engaged in precmptive behavior. For an analysis of preemption by the executive branch, see Foote, Administrative Preemption: An Experi- 
OSHA right-to-know rule that preempted many protective state statutes, and federal product hability legislation that would remove the traditional autonomy of the state courts in tort law. Both positions would greatly increase the power of the central government at the expense of the states and appear to be based on partisan rather than neutral principles.20

While the judiciary may be aware of the political implications of the separation of powers argument, it is not certain whether or how much politics lias influenced its analysis. It is widely believed that Justice Scalia authored the lower court opimion in Bowsher v. Synar prior to his elevation to the Supreme Court. ${ }^{21}$ Justice Scalia, once a member of the Justice Department's Office of Legal Counsel, was not unaware of any political implications, both in relation to Gramm-Rudman and the broader sweep of the arguments. Indeed, the opinion makes direct reference to the political context of the case:

It may seem odd that this curtailment of such an important and hardfought legislative program should hinge upon the relative techıricality of authority over the Comptroller General's removal ... [b]ut the balance of separated powers established by the Constitution consists precisely of a series of techurical provisions that are more important to liberty than superficially appears, and whose observance cannot be approved or rejected by the courts as the times seem to require. ${ }^{22}$

And, in dicta, there is a discussion of the status of independent agencies in relation to the separation of powers doctrine. The court finds the relevant precedent on the issue of removal of officers "stamped with some of the political science preconceptions characteristic of its era and not of the present day." 23 The court then raises questions about the contemporary justifications for the existence of imdependent agencies. While there is no direct attack on the constitutionality of this form, doubts about its viability are clearly imtimated. ${ }^{24}$

It may simply be a happy accident that well-known conservative Reagan appointee Scaha's primcipled judicial stance, subsequently af-

ment in Regulatory Federalism, 70 VA. L. REV. 1429 (1984); Foote, Regulatory Vacuums: Federalism, Deregulation, and Judicial Review, 19 U.C. DAVIS L. REV. 113 (1985).

20. See Gray, supra note 18, at 96-106. For a critique of Gray's approach, see Foote, Beyond the Politics of Federalism: An Alternative Model, 1 YALE J. REg. 217 (1984).

21. Dwyer, The Gramm-Rudman Ruling May Turn into a Deadly Weapon, Bus. Wk., Mar. 3, 1986, at 36; Kinsley, supra note 17 , at 25 , col. 3 .

22. 626 F. Supp. 1374,1403 (1986).

23. Id. at 1398 .

24. It is not as obvious today as it seemed in the 1930 s that there can be such things as genuinely "independent" regulatory agencies, bodies of impartial experts whose independence from the President does not entail correspondingly greater dependence upon the committees of Congress to which they are then immediately accountable; or, indeed, that the decisions of such agencies so clearly involve scientific judgment rather than political Id. choice that it is even theoretically desirable to insulate them from the democratic process. 
firmed by the Supreme Court, coimcided with his political preferences and those of the President who appointed him. There is nothing in the case that would suggest to me that politics, ratlier than constitutional principles, guided the arguments. ${ }^{25}$

Theories of federalism provide a useful analog to the formal approach detailed above. Federalism also involves principles of separation of powers, albeit between levels of government rather than among federal branches. After reviewing Supreme Court decisions on federalisin, one can conclude that members of the Court appear to apply neutral principles of constitutional law regardless of the political outcoine in any particular case. California Coastal Commission v. Granite Rock Co. ${ }^{26}$ illustrates the point. The issue before the Court was whether the California Coastal Commission could require inining companies conducting federally approved mining activities on federal land to comply with state environmental permit requireinents. The mining company, Gramite Rock, sued to enjoin the California commission from compelling it to comply. The political alignments were predictable. The Reagan administration sided with the mining company, arguing that the federal government preempted the states. (So mucli for states' riglits!) ${ }^{27}$ Environmentalists supported California, jomed by nineteen states, the Western Governors' Association, and other state organizations.

How the Justices lined up is imstructive. The conservative justices did not support the administration's arguinents. Indeed, the autlior of the opinion that upheld Cahifornia's environinental policies was a Reagan appointee, Justice Sandra Day O'Connor. She was joined by Justices Rehnquist, Brennan, Marshall, and Blackmun-strange bedfellows if politics were the deciding factor. Justice Powell dissented in part, on the grounds that federal agencies had already considered the environinental effects of the mining and that the state should not impose a separate and duplicative pernit system. Justice Scalia, joined by Justice White, dissented on similar grounds. ${ }^{28}$

In other cases involving disputes between federal and state governments, the Supreme Court apparently has not divided on purely political

25. Before Morrison v. Olson was clecided, 108 S. Ct. 2597 (1988), many viewed the special prosecutor case as "profoundly political." Alfred Kahn, for example, argued that if the Supreme Court were to sustain the decision of the D.C. Circuit and the official position of the Administration itself, "it will be impossible to escape the suspicion that the decision was political." Kahn, The Special-Prosecutor Stakes, N.Y. Times, May 9, 1988, at A19, cols. 1, 3.

26. 107 S. Ct. 1419 (1987).

27. See supra note 18.

28. 107 S. Ct. at $1422,1432,1438$. 
lines. ${ }^{29}$ Of course, the Justices must follow congressional intention to preeinpt the states. However, that intention inay be sufficiently obscure so that the Court engages in federalisin balancing. To the extent that there is an observable pattern in their decision, it is that Justices Rehnquist and O'Connor are more likely to rule in favor of the states; Justice Blackmun and former Chief Justice Burger are inore likely to fall on the federal side. If these patterns inean anything, they may reflect federalism preferences. But they cannot be explained by partisan politics, as the Granite Rock case so clearly demonstrates.

\section{A. The Functional Critique.}

The critique of the organizational form of independent agencies in the literature seems based on neutral principles of accountability and efficiency. However, much of the present debate pays shight lip service to principles of government, and is blatantly political in nature. A closer look at two structural reform proposals illustrates the short-term political nature of the debate.

Concerned about deteriorating aircraft safety, Congress mandated a study of the problems of Federal Aviation Administration (FAA) regulation. The President was empowered to appoint a study commission, which released its final report on April 18, 1988. ${ }^{30}$ It called for a "major structural overhaul" of the Federal Aviation Administration. A key recommendation was to inake the agency independent of the Department of Transportation, a traditional executive agency. Oversight of the new FAA would be vested in a nine-ineinber board appointed by the President and confirmed by the Senate. There would be two officials appointed to seven-year terms, an admmistrator to manage the new agency, and a director of aviation safety to oversee regulations. The purpose of these structural changes, according to the panel, is to free the agency from the management of the Departinent of Transportation and from

29. See, e.g., Transcontinental Gas Pipe Line Corp. v. State Oil and Gas Bd., 474 U.S. 409 (1986). In a 5-4 decision, the Court upheld preemption by the federal government of state regulation of ratable-take contract rules. Blackmun delivered the opmion of the Court in which Burger, Brennan, White and Marshail joined. Rehnquist dissented, joined by O'Connor, Powell and Stevens. See also Virginia State Corp. Comm'n v. FCC, 737 F.2d 388 (4th Cir. 1984), rev'd sub nom. Louisiana Pub. Serv. Comm'n v. FCC, 476 U.S. 355 (1986). The Supreme Court reversed the Fourth Circuit's allowance of FCC preemption of state depreciation policies for state share of jointly used telephone equipment. The decision was 5-2, with Brennan, Rehnquist, Stevens, White and Marshall in the majority. Burger and Blackmun dissented without opinion. For further discussion of these and other cases, see Foote, New Federalism or Old Federalization: Deregulation and the States, in PERSPECTIVES ON FEDERALISM 41 (H. Scheiber ed. 1987).

30. At the time of this writing, the author was unable to obtain copies of the recently released report. Descriptions of the recommendations are based on contemporaneous news reports. 
control by the Office of Management and Budget. ${ }^{31}$

Predictably, the Reagan Administration was highly critical of the proposal. Transportation Secretary James Burnley said: "Safety regulation and enforcement must remain subject to strict control and oversight by the federal government." 32 Some members of Congress, however, welcomed the report, which supported a pending Senate bill, the Federal Aviation Administration Independent Establishment Act of 1987. The legislation would, among other reforms, create an independent FAA. ${ }^{33}$ Clearly Congress expects to liave greater influence over tlie regulation of air safety with an independent agency in charge.

Both Representative Henry Waxman (D., Cal.) and Senator Albert Gore (D., Ky.) have introduced legislation to change the appointment process of the Commissioner of the Food and Drug Admimistration (FDA). The primary provision of both bills would make the Commissioner subject to Senate confirmation upon nomination by the President. ${ }^{34}$ Presently, the Commissioner is appointed by the President with no congressional involvement. The legislators do not provide justification for this change based on any neutral primciples of good government. Indeed, all the reasons presented in the legislative history are political ones. To Congress, independent means more congressional oversight:

The Committee believes that Senate confirmation is a constructive and worthwhile process. It is a procedure tliat provides the Congress with an invaluable opportunity for oversiglit. It is a procedure that should apply to persons appointed to serve as Commissioner of the Food and Drug Administration. ${ }^{35}$

The primary justification for the change is that all other major federal health and safety agencies require Senate confirmation of presidential appointees. ${ }^{36}$ These agencies were formed in the 1960s and 1970s, when a powerful Congress woil greater agency autonoiny from the executive branch. Much of the legislation enacted during that period experi-

31. Witkin, Powerful New Role Is Unged for FAA on Airline Safety, N.Y. Times, Apr. 19, 1988, at Al, cols. 1, 2; McGinley, Air Safety Panel Seeks Independence for FAA as Part of a "Major Overhaul," Wall St. J., Apr. 19, 1988, at 2, col. 2.

32. McGinley, supra note 31. It is interesting that by the term "federal government," Burnley means the executive branch, not Congress or independent agencies. 1987).

33. S. 1600 , 100th Cong., 1st Sess. $§ 4,133$ Cong. Rec. $\$ 11,473$, S11,473 (daily ed. Aug. 6,

34. H.R. 1226, 100th Cong., 1st Sess. sec. 1, § 904, 133 CONG. REC. H3025, H3025 (daily ed. May 4, 1987); S. 223, 100th Cong., 1st Sess. § 3(a), introduced, 133 CoNG. REc. S154 (daily ed. Jan. 7, 1987).

35. H.R. ReP. No. 70, 100th Cong., 1st Sess. 2 (1987).

36. The list includes the Federal Aviation Administration, the Environmental Protection Agency, the Occupational Safety and Health Adininistration, the Consuner Product Safety Coinmission, and the Nuclear Regulatory Commission, as well as other entities within the Department of Health and Human Services. Id. 
mented with a variety of procedural and structural forms to ensure that administrative agencies would pursue the goals of the law. ${ }^{37}$ The FDA, by contrast, has its roots in the Progressive era, and its ties to the executive branch are due to historical accident, not inequitable treatment. ${ }^{38}$ Predictably, the Reagan administration opposes this legislation to increase congressional oversight of the FDA. The tension between the branches is illustrated by the following exchange between Representative Waxman and Senator Gore. Gore testified before Waxman's subcommittee:

Mr. WaXMan. . . . Let me just ask you one question. The administration is going to testify later today that they think it is unnecessary for the Senate to confirm the Food and Drug Administration Commissioner. I suppose they would think it is unnecessary to have confirmation for solne of the appointments which have to go to the Senate for confirmation.

But, do you think that there is any adverse effect on the independence of an FDA Commissioner from the administration, by having the requirement that the Commissioner go before the Senate for confirmation?

Mr. GoRE. ... I do not think so. Indeed, I think it would enhance that person's independence, because imstead of being subject to the whim of an immediate superior, he would have the extra insulation afforded by this new role played by a second branch of Government.

37. In 1976, Congress passed the Medical Device Amendments to the Food, Drug and Cosmetic Act. Pub. L. No. 94-295, 90 Stat. 539 (1976). Advocates of the legislation in Congress wanted to ensure that the law would be properly implemented. The concerns of Representative Rogers (D Fla.), one of the authors of the bill, are reflected in subsequent correspondence with the Commissioner of FDA. Rogers wrote:

During consideration of the medical device legislation ... I was innnndated [sic] with assertions that the Food and Drng Administration would implement the proposed new law the way it wished, without regard to legal requirements. My response to these assertions was twofold: First, the legislation would be written in a detailed fashion so that all affected parties (mcluding the Food and Drug Administration) would know their rights and responsibilities. Second, the Subcommittee would monitor the implementation of the legislation to insure FDA actions comported with the requirements of law and the intent of Congress.

Letter from Rep. Paul Rogers to Alexander M. Schmidt, Commissioner of FDA, June 21, 1976, reprinted in Foote, Administrative Preemption, supra note 19, at 1446 n.74.

38. The Pure Food and Drug Act of 1906 was passed in the wake of adverse publicity concerning adulterated food prodncts. One of the prime supporters of federal action was one Dr. Harvey Wiley, who was a chemist for the United States Department of Agriculture. The admimistration of the new law was placed in his Bureau of Chemistry. Numerous amendinents were passed in subsequent years, including the creation in 1927 of a separate law-enforcement agency known as the Food, Drug and Insecticide Admmistration, later the Food and Drug Administration. Following the passage of the Federal Food, Drug and Cosmetic Act in 1938, FDA was transferred from the Department of Agriculture to the Federal Security Agency. The FSA became the U.S. Department of Health, Education, and Welfare in 1953, and more recently the Department of Health and Human Services. See generally H. Neal, The Protectors: The Story of the Food and DRUg AdMINISTRATION (1968). 
As for the expected, or the mentioned, opposition on the part of the administration, I would urge the subcommittee to heavily discount that as merely a knee-jerk reaction. ${ }^{39}$

It is clear that the issue is not government structure for its own sake. There appears to be no colierent theory of why agencies have been designed to be executive or independent in any particular case. The diversity of forms is, in the words of Peter Strauss, "characteristic of our pragmatic ways with governunent, reflecting the circumstances of the particular regulatory regine, the teinper of presidential/congressional relations at the time, or the perceived success or failure of an existing agency performing like functions, inore than any grand scheme of governinent." 40 In the case of FIDA, it is a political conflict between Deinocrats in the Congress and a Repubhican administration. ${ }^{41}$ Pohtics inatter, and structure is a weapon in the battle.

The participants in the debate all assume that structural changes will affect outcoines. The inore pragmatic question is wliether or how much form really inatters.

\section{B. The Limitations of Form.}

If structure matters to pohtical outcoines, one would expect to see the executive brancli exert greater influence over executive agencies, and Congress to have more influelice over independent ones. Several political scientists have tried to measure the influence of Congress and the executive branch on independent agencies. The results are instructive. In their study of the Federal Trade Commission (FTC), a classic independent agency, Weingast and Moran challenged the arguinent that regulatory agencies are largely autonomous. ${ }^{42}$ Using data analysis of FTC activities froin 1966 to 1979 , they concluded that the agency was tied closely to the congressional subcommittee charged with oversight. ${ }^{43} \mathrm{Be}$ cause FTC had strong structural ties to Congress, this conclusion supports the view that structure inatters. However, the authors make

39. Senate Confirmation of the FDA Commissioner; and Reauthorization of Research Activities by ADAMHA: Hearings on H.R. 3909 Before the Subcomm. on Health and the Environment of the House Comm. on Energy and Commerce, 99th Cong., 2d Sess. 6 (1986).

40. Strauss, The Place of Agencies in Government: Separation of Powers and the Fourth Branch, 84 Colum. L. REV. 573, 584-85 (1984).

41. Newspaper reports suggest that the Reagan Admimistration had instituted changes at FDA that affected the independence of FDA scientists. These moves included transferring authority to HHS to decide important issues, and strengthening the power of the Office of Management and Budget. Administration and FDA officials declined to comment on the legislation. Specter, The FDA's Declaration of Independence, Wash. Post, Feb. 22-28, 1988, at 34, col. 1 (weekly ed.).

42. Weingast \& Moran, Bureaucratic Discretion or Congressional Control? Regulatory Policymaking by the Federal Trade Commission, 91 J. PoL. EcoN. 765 (1983).

43. Id. at 791-92. 
another point that is noteworthy. Their research indicates that congressional influence over agency choices can occur without systematic, continuous, or pubhicly held oversight hearings. ${ }^{44}$ In other words, there are many informal mechanisins of control.

Informal influences can follow formal ties and strengthen thein; $m$ formal influences can also transcend or supersede formality. The work of another political scientist, Terry Moe, underscores the importance of informal control. ${ }^{45}$ Moe studied several independent agencies, including FTC, during the same period as Weingast and Moran. He asked: "Has presidential influence been exercised in such a way as to brimg about changes in the general direction of commission behavior?"46 Arrived at through formal einpirical modeling techniques, Moe's findings suggest that regulatory behavior does shift across administrations, and that it varies systematically with presidential partisanship. Presidents apparently do achieve a measure of direction and control over mdependent agencies.

Several tentative conclusions can be drawn froin these empirical analyses. The most important is that there is not one set of influences defined by formal relationships. Both Congress, often through its subcommittees, and the executive have means by which to influence regulatory decisions. The pohtical outcoines cannot be predicted simply by a look at the formal ties of government. The political environment, and the nature of political pressure, is much more complex and subtle.

While I have not performed statistical analyses coinparable to the work of Moe and Weingast, observations of the present political environinent support the conclusion that executive and congressional influences are not restrained by formal relationships to agencies. A brief look at three different federal agencies will illustrate the point.

It is well-known that the executive branch was quite strong vis-à-vis Congress during the first term of the Reagan Administration. The Administration has exercised a significant influence on regulatory agencies. The Occupational Safety and Health Administration (OSHA), an executive agency within the Department of Labor, lias fallen prey to the Admimistration's lack of commitment to health and safety. ${ }^{47}$ There have been drastic cuts in budget and staff. The research arin of OSHA has a

44. Id. at 792.

45. Moe, Regulatory Performance and Presidential Administration, 26 AM. J. PoL. ScI. 197 (1982).

46. Id. at 197.

47. See Trost, Occupational Hazard: A Much-Maligned OSHA Confronts Rising Demands with a Reduced Budget, Wall St. J., Apr. 22, 1988, at 25R, col. 1. 
budget less than half of what it was eight years ago (in 1980 dollars). 48 Because OSHA is an executive branch agency, significant reductions in its activities reflect a lack of administration support. This result would not challenge the view that structure matters. ${ }^{49}$

However, the administration has had an equally poweful impact on another safety agency, the Consumer Product Safety Commission (CPSC), which is formally independent. CPSC was born during the heyday of the consuiner inoveinent. Congress wanted a visible independent commission that was not buried "in the bowels of soine large executive department." 50 Despite its independent status, CPSC has atrophied in the hands of the present admimistration. In 1981, former budget director David Stockman tried to abohish it. Although he did not succeed, CPSC's staff has been cut by more than forty percent and its budget by almost a quarter since 1981. ${ }^{51}$ CPSC has become, if not a do-nothing, a do-very-little agency. There have been reports of conflict among the commissioners, and their decisions are characterized by inaction and excessive delays. For exainple, CPSC acknowledged that cigarette highters were a major cause of child deaths, but waited nearly three years to take any action. One disgruntled staffer said: "The signal froin above appears to be that we really don't want you to do anything, so you kind of just sit back and you don't push for anything." "s2

In some cases, however, there have been constraints on the power of the admimstration. The need to cut back on environmental protection was one of Reagan's cainpaign theines. ${ }^{53}$ The National Journal reported on the eve of the 1981 inaugnration: "[I] $f$ anything can be predicted in the new Administration, it is an effort to trim the powers of the Environmental Protection Agency (EPA) and other environmental regulators." 54 EPA is considered an independent agency within the executive branch..$^{55}$ The Administrator is appointed by the President and confirmed by the

48. Id. at $26 \mathrm{R}$, col. 3 .

49. Congress is now becoming more aggressive in support of OSHA. During April 1988, Senator Kennedy (D - Mass.) charged that the agency was lax in its enforcement. Both the Assistant Labor Secretary and the OSHA Administrator testified at recent Senate Hearings. Kennedy commented: "We're going to have a new Administration after this fall and, hopefully, we can get this agency back on track again." author, OSHA Chief Denies "Retreat from Safety," N.Y. Times, Apr. 21,1988 , at 25, col.1 (late ed.).

50. M. REAGAN, supra note 1, at 49.

51. Waldman, Kids in Harm's Way, NEwsweEK, Apr. 18, 1988, at 47-48.

52. Id.

53. M. DerThick \& P. QUirk, The Politics of Deregulation 212 (1985).

54. Mosher, Reagan and Environmental Protection-None of the Laws Will Be Untouchable, 13 NAT'L J. 17 (1981).

55. 40 C.F.R. $\S 1.1$ (1987). 
Senate. The President has authority to discharge the Administrator at will.

However, structure does not confer power without consequences. Reagan appointed William Ruckelshaus to serve as Administrator after Anne Gorsuch Burford resigned in the midst of strong criticism. Strauss concluded: "Even in executive agencies, the layer over which the President enjoys direct control of personnel is very thin and political factors may inake it difficult for him to exercise even those controls to the fullest. An administrator with a public constituency and mandate, such as Wilham Ruckelshaus, cannot be discharged-and understands that he cannot be discharged-without substantial political cost." 56

To account for the varying influences of politicians, both executive and legislative, one must look at the entire political environment. Furthermore, that political context is more than just a tug of war between Congress and the Executive. Indeed, there is empirical evidence for the view that regulatory agencies are influenced by a wide range of factors, including Congress, the President, and the courts, as well as agency staffs and economic conditions. ${ }^{57}$ In addition, there are important influences in the private sector. Some studies of interest groups, particularly the regulated industries, find powerful effects on regulatory outcomes. ${ }^{58}$ The influence of industry can be so substantial that many have expressed concern about agency "capture."59 Public opinion also helps shape the preferences of the politicians. Martha Derthick and Paul Quirk have analyzed the complex array of political and social forces that brought economic deregulation in 1975-1980.60

Another look at FDA illustrates the importance of all the public and private imterests im shaping administrative behavior. FDA is fully embedded in the executive branch. Although cominitted to reducing regulation, President Reagan never directly attacked the existence of FDA. And, his often-used techniques of budget cutting met witl resistance from all sides. Why?

It is clear that there has always been public sentiment in favor of safe medical products. Despite frustrations with FDA on specific issues, public support has rarely wavered. Congress has remained active in its oversight role, and has been quick to criticize the agency for inaction. ${ }^{61}$

56. Strauss, supra note 40 , at 590 (footnotes omitted).

57. Moe, Control and Feedback in Economic Regulation: The Case of the NLRB, 79 AM. PoL. SCI. REv. 1094, 1095 (1985).

58. See, e.g., The Polmics of Regulation (J. Wilson ed. 1980).

59. See supra note 5 .

60. M. DERTHICK \& P. QUIRK, supra note 53.

61. In 1979, the American Enterprise Institute reported that drug regulation engendered more congressional inquiries and General Accounting Office (GAO) reports than any other area of regula- 
It is interesting that the industries regulated by FDA have not advocated its demise. One explanation is the nature of FDA's inandate, particularly over drug safety. In order to get a drug on the market, FDA must review the premarket approval apphication. FDA provides a barrier to entry. Budget and staff cuts simply delay the decisions of the agency; no pharmaceutical coinpany benefits by this type of "deregulation." Second, FDA provides credibility to the pharmaceutical imdustry by placing its imprimatur on approved products. And, the availability of unified federal action las served the drug industry well in certain instances. Following the Tylenol tampering episode in 1980, inanufacturers of overthe-counter products used FDA to get mandatory, uniform packaging requirements. FDA's speedy response helped restore credibility to the industry and prevented costly marketing coinpetition on tamper-proof packaging options. ${ }^{62}$ Finally, the requirement of FDA approval has been use to support qualified immunity froin tort hability for drug products. ${ }^{63}$

When powerful members of Congress ally with public interest groups and industry, the executive branch is severely constrained despite its formal authority. Political alliances can vary in different circun1stances, and these forces need to be studied with care. For example, during the toxic shock crisis, other companies in the highly competitive feininine hygiene market did not come to the defense of Procter and Gamble, the producers of Rely brand tampons. FDA, under pressure from the public to act, and presented with a badly divided industry, inanaged to isolate an industry giant and negotiate a consent decree. ${ }^{64}$ The shifting alliance ainong the many stakeholders significantly affects regulatory outcomes in any particular case.

tory law. American ENTERprise INSt. for Pub. Policy Research, Proposals to Reform Drug Regulation Laws 1 (1979) (Legislative Analysis No. 8, 96th Congress). FDA was recently criticized by Congress for failure to aggressively regulate medical devices. See SUBCOMM. ON OVERSIGHT \& INVESTIGATIONS OF THE HOUSE COMM. ON ENERGY \& COMMERCE, 98TH CONG., IsT Sess., Medical Device Regulation: The FDA's Neglected Child (Comm. Print 1983).

62. 21 C.F.R. § 211.132 (1988).

63. Compliance with FDA requirements has never been an absolute defense to product liability actions. Such a defense has been proposed by the Pharmaceutical Manufacturers Association in federal product hability reforn proposals. A recent appellate court decision in California, Collins v. Ortho Pharmaceutical Corp., 195 Cal. App. 3d 1539, —, 231 Cal. Rptr. 396, 404 (1986), held that any prescription product that requires FDA approval is unavoidably unsafe as a matter of law and thus outside the parameters of strict liability for defective desigu. The case is pending before the California Supreme Court. Id. at -, 231 Cal. Rptr. at 396, rev. granted sub nom. Collins v. Karoll, - Cal. 3d -, 732 P.2d 542, 234 Cal. Rptr. 596 (1987); see also 186 Cal. App. 3d 1194 (1986) (deleting Court of Appeal decision and noting grant of review).

64. For a detailed discussion of the Rely case, see Foote, Corporate Responsibility in a Changing Legal Environment, CAL. MGMT. REV., Spring 1984, at 217, 220-25. 


\section{CONCLUSION}

The two critiques of independent agencies can be presented in a nonpohtical, neutral light. The Reagan administration and its supporters are using these critiques to further purely partisan ends, although it is less clear whether the inembers of the judiciary have pursued the constitutional challenge for pohitical reasons. Liberals in Congress reject these two critiques because of their own present political posture.

The more pragmatic question is whether this debate, regardless of the inotives of the participants, will ultimately affect the behavior of independent agencies. Does the structure of administrative agencies inatter? My answer is a resounding "it depends." Independence is one factor among inany in the coinplex pohitical environment in which regulatory policy is made. When Congress is strong, it can impose its imprint on the structure of the administrative state through the creation of independent agencies. When the balance of power shifts, however, formal structures cannot prevent pressure, even domination, by the executive branch. There are many other critical factors that influence regulatory outcoines, including powerful business interests and the public at large.

My answer should be reassuring to those who fear serious political upheavals if the fornal separation of powers doctrine succeeds in its challenge to independent agencies. Separation of powers may be of greater importance to constitutional theorists than to regulators. And, if theory is merely a cover for pohtical views, the approach will backfire. Not only does the power of the executive and legislative branches shift over time, but their politics do as well. Pohtical conservatives may well discover that their efforts to strengthen the executive brancin will come back to haunt them when there is a new occupant in the White House.

Woodrow Wilson once wrote: "[G]overnment is not a nachine, but a hiving thing. ... No living thing can have its organs offset agaimst each other as cliecks, and live."65 Excessive rehance on form, whether for constitutional or functional reasons, is short-siglited and probably irrelevant. All institutions of government, including independent agencies, are subject to the complex political influences that characterize a deinocratic state. My guess is that the organisms of government will survive any effort to impose rigid forinal structures upon thein.

65. W. WILSON, CONSTrTUTIONAL GOVERNMENT IN THE UNITED STATES 56 (1908). 